\title{
Dilemmas of European Migration Policies: Failure of Sea Rescue in the Mediterranean or Successful Externalization of Borders?
}

\author{
Patricia Schneider
}

\begin{abstract}
Discussions about migration and security are often characterized by emotions and symbolic images, for example of capsizing, overcrowded boats with desperate people or of seemingly unmanageable queues of migrants in front of border crossings. State and non-state actors confront these uncertainties through maritime migration with different missions. This article provides an overview of these missions over time and in the context of refugee routes used. Different understandings and a lack of regulations have their core, among others, in the fact that classical sea rescue of shipwrecked seafarers differs from the phenomenon of induced distress situations for unauthorized border crossing. Reception seems morally imperative, but political consensus is lacking. The obligation to rescue endangered persons at sea as well as to examine asylum claims after border crossings are being circumvented partially. In governing the migration issue, the EU and its member states face several dilemmas. The article highlights selected dilemmas of European migration policies and addresses the question of whether we are witnessing a failure of sea rescue in the Mediterranean or a successful externalization of borders. In the outlook, policy options are outlined.
\end{abstract}

Keywords: Sea Rescue, Search and Rescue, migrants, EU, migration policies, borders, maritime operations

Schlagwörter: Seerettung, Seenotrettung, Migranten, EU, Migrationspolitik, Grenzen, maritime Missionen

\section{Introduction}

$\mathrm{M}$ igration is a highly emotional topic, often used for political mobilization. Discussions of migration are often driven by emotion and symbolic images for example, of capsizing, overcrowded boats with desperate people or of unmanageable lines of migrants in front of border crossings. These images can trigger compassion for the suffering of the migrants and perhaps an immediate impulse to help. They can help to identify with Angela Merkel's optimistic statement "Wir schaffen das!" ("We can do this!") in summer 2015 and later, "Europe will manage this". Others relate more to Nigel Farage's pessimistic Brexit campaign poster depicting a long queue of so-called 'economic migrants' at the EU border maybe triggering a sense of being 'invaded'. Or people might feel emotionally trapped between the two. Annette Jünemann discussed the co-relation of empathy and fear and recommends direct contact and unfiltered communications in peer-group settings (Jünemann, Scherer, and Fromm 2017:181).

In an earlier issue of S+F, I presented German and European migration policy more broadly in the context of peace and security (Schneider 2016). This article addresses the highly controversial topic of sea rescue in the Mediterranean as a case of European migration policy. It focuses on empirical data as well as on selected dilemmas of European migration policy and related concepts from political science when answering the question whether we experience a failure of sea rescue in the Mediterranean or a successful externalization of borders. In this article, I therefore critically examine different assessment of the EU's policies towards sea rescue in the Mediterranean. To understand the role of the different military, police and private rescue missions, I will first outline migrations routes and then turn to past and current reactions.

I will use the term migrant as an umbrella term for people on the move for mixed reasons, because the people taking boats are like most groups of people who cross EU external borders; they consist of "refugees, other people in need of protection, but also people without any accepted grounds for protection" (Parusel 2020:42). For example, in May 2020, the United Nations High Commissioner for Refugees (UNHCR) estimated that " $28 \%$ of the people who had crossed the sea from Libya are likely to be in need of international protection" (UNHCR 07.07.2020).

I define border externalization as border control no longer taking place at the physical borders of the European Union, but being exercised by external actors, a matter which is strongly debated (UN Human Rights Council 24.04.2013:14; Guild 2016; Fernandez 2016; Frelick, Kysel, and Podkul 08.08.2016; Reinke de Buitrago 2017; Cusumano 2018; Liguori 03.2019; Ärzte ohne Grenzen 03.04.2019; Deleixhe and Duez 10.2019; Vradis, Papada, and Painter 15.11.2019; Bossong 10.2019).

This article argues that different understandings and a lack of regulations have their core, among others, in the fact that classical sea rescue of shipwrecked seafarers differs from the phenomenon of induced distress situations for unauthorized border crossing. Reception seems morally imperative, but political consensus is lacking. The obligation to rescue as well as to examine asylum claim (Liguori 03.2019) after border crossings are being circumvented partially. In governing the migration issue, the EU and its member states face several dilemmas. The dilemmas prevent real progress toward effective asylum and migration policies, and the resulting deadlock prevents solidarity from being provided to overburdened EU frontline states as well as to the migrants. If we measure the success of EU border protection in terms of the number of arrivals or irregular border crossings, it seems to be successful. This seeming success story is undermined when we measure migration policies in terms of successful rescues. The externalization of border controls also in terms of sea rescue has further reduced the success because, on the one hand, the safe place for the rescued is not established and, on the other hand, the EU Member States and Frontex are 
themselves involved in illegal pushback practices. I argue that these are, in fact, cases in which European States fail to perform their obligation to rescue. Though effectively leading to a decline of arrivals, under these conditions they do not reflect legitimate and legal border externalization.

The essay is divided in five sections: Section one deals with discussing the question of whether the decline in EU rescue missions constitutes a failure to rescue or legitimate border closure and externalization of borders; I will proceed in three steps. Section two outlines instances of sea rescue as cases of EU migration policy. I trace the numbers as well as the successes and decline of these missions in recent years. In section three I address the main question of this article and defend my claim that indeed border externalization can be an effective instrument but here presents rather a failure to rescue than legitimate border closure. I discuss the disputed nature of these maritime emergencies as well as to the debate on open borders vs. border externalization policies. In section four I turn to policy challenges we are faced with in implementing a regulatory framework and present a glimpse towards ways forward before I turn to my conclusions in section five.

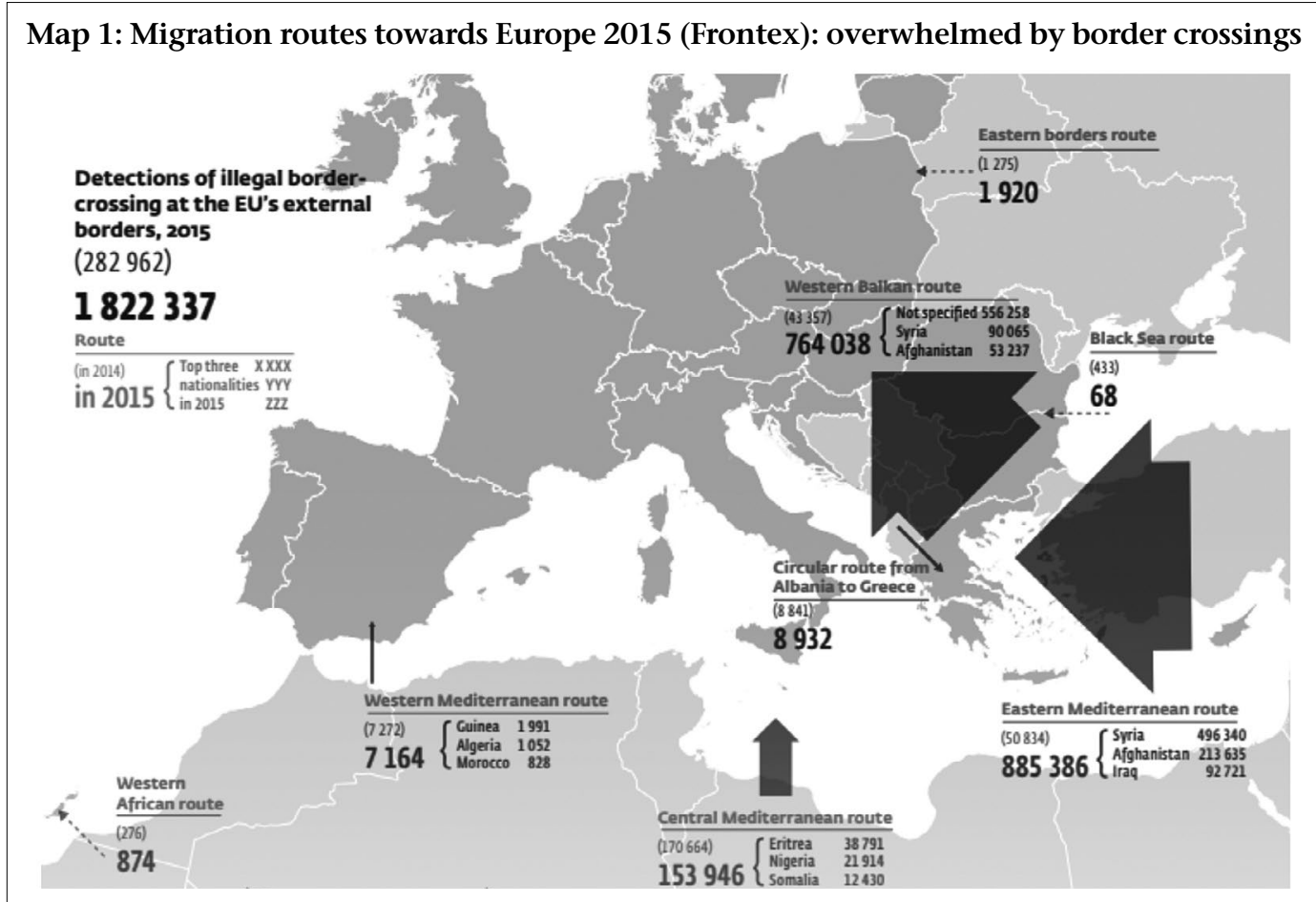

Map 2: Migration routes towards Europe 2019 (Frontex): significant decrease of arrivals

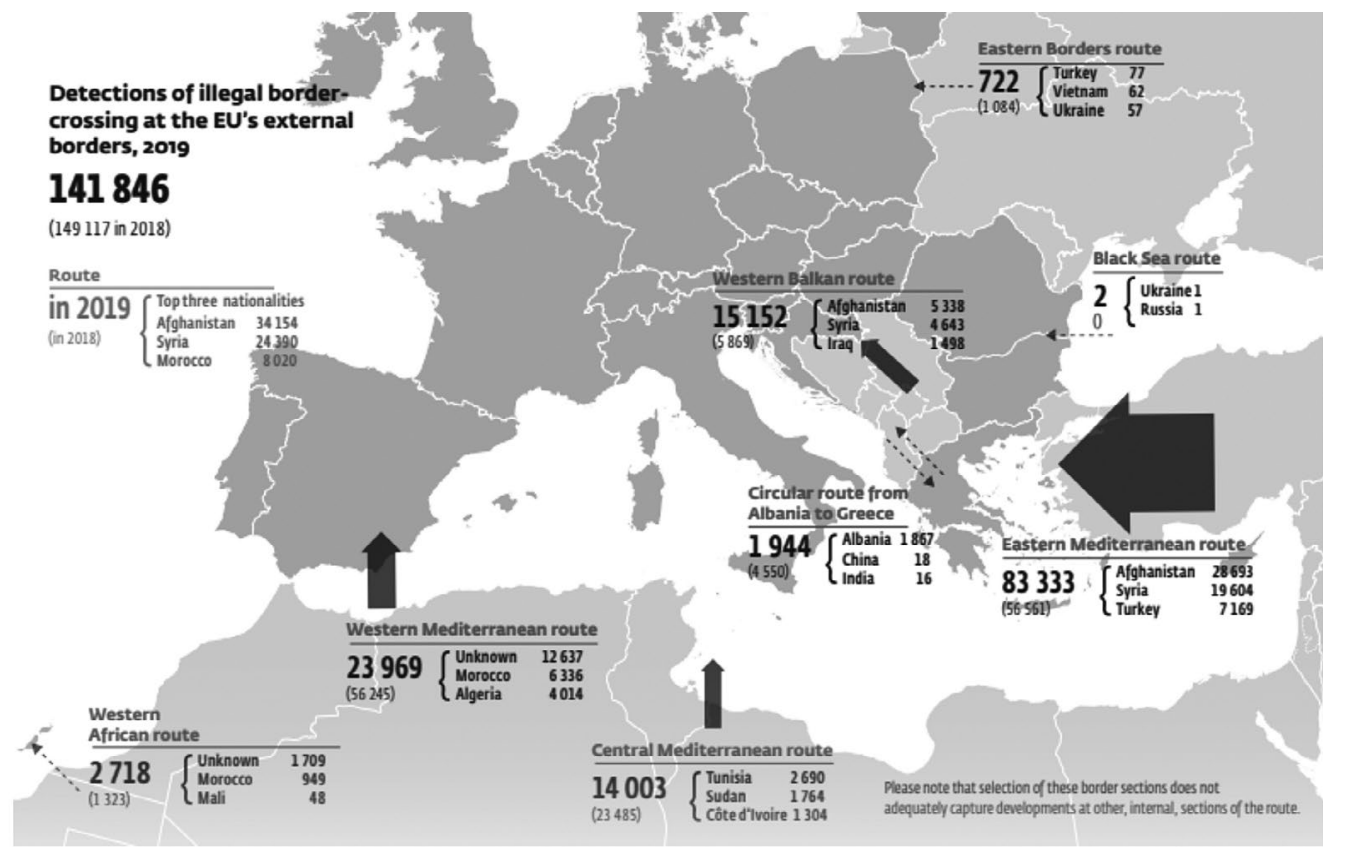

\section{Sea Rescue in the Mediterranean as a Case of EU Migration Policy}

\subsection{The Migratory Situation in Europe: Routes and Arrivals}

In order to be able to judge whether the externalization of the European borders and/or the sea rescue are successful, it is necessary to look at the development of routes, arrival figures and the number of dead and missing persons. A low number of arrivals or irregular border crossings could indicate a successful policy of border externalization. A high number of rescued persons and a low number of dead and missing persons at sea could indicate a successful rescue policy.

I will first present an overview of the Annual Frontex Risk Analysis reports. It summarizes the available data on border crossings at the EU's external borders provided by Frontex (Frontex 03.2016, 03.2020). The numbers on the first map (see map 1) refer to 2015, and the numbers in brackets to 2014 . In 2014, there were almost 300,000 arrivals. The situation in 2015 represents the peak, with a rise to more than 1.8 million irregular migrants travelling to Europe. This equals 
the population of Hamburg, Germany's second largest city. The majority, including the following years, were sea arrivals. The migrants mainly came from Syria and Afghanistan, but in 2015 the authorities were overwhelmed. They could not identify the origin of almost a third of them - more than 500,000 people.

In 2019 , the numbers fell considerably, to about 140,000 irregular ${ }^{1}$ border crossings (see map 2 ). ${ }^{2}$ This trend continued in 2020 (see table 1 ).

Table 1: Migratory situation in Europe in 2020 (Frontex data, land and sea routes) ${ }^{3}$

\begin{tabular}{|c|c|c|c|}
\hline Routes usage & $\begin{array}{l}\text { Number of } \\
\text { irregular } \\
\text { border } \\
\text { crossings }\end{array}$ & $\begin{array}{l}\text { Percentage } \\
\text { change in } 2020 \\
\text { compared to } \\
2019\end{array}$ & $\begin{array}{l}\text { Top } 5 \\
\text { countries of origin }\end{array}$ \\
\hline $\begin{array}{l}\text { 1. Central } \\
\text { Mediterranean }\end{array}$ & 35,628 & +154.43 & $\begin{array}{l}\text { Tunisia: } 12,933 \\
\text { Bangladesh: } 4,363 \\
\text { Côte d'Ivoire: } 1,960 \\
\text { Sudan: } 1,674 \\
\text { Algeria: } 1,464\end{array}$ \\
\hline 2. Western Balkan & 26,928 & +77.72 & $\begin{array}{l}\text { Syria: } 16,684 \\
\text { Afghanistan: } 5,187 \\
\text { Iraq: } 729 \\
\text { Palestine: } 645 \\
\text { Libya: } 631\end{array}$ \\
\hline 3. Western African & 22,619 & +732.19 & $\begin{array}{l}\text { Morocco: } 6,319 \\
\text { Unspecified sub-Saharan } \\
\text { nationals: } 4,453 \\
\text { Mali: } 290 \\
\text { Senegal: } 95 \\
\text { Côte d'Ivoire: } 93\end{array}$ \\
\hline $\begin{array}{l}\text { 4. Eastern } \\
\text { Mediterranean }\end{array}$ & 19,681 & -76.38 & $\begin{array}{l}\text { Syria } 4,287 \\
\text { Afghanistan: } 3,650 \\
\text { Turkey: } 3,626 \\
\text { Unknown: } 1,222 \\
\text { Somalia: } 875\end{array}$ \\
\hline $\begin{array}{l}\text { 5. Western } \\
\text { Mediterranean }\end{array}$ & 17,057 & -28.84 & $\begin{array}{l}\text { Algeria: } 11,287 \\
\text { Morocco: } 3,566 \\
\text { Unspecified sub-Saharan } \\
\text { nationals: } 1,799 \\
\text { Mali: } 88 \\
\text { Guinea: } 78\end{array}$ \\
\hline $\begin{array}{l}\text { 6. Circular route } \\
\text { from Albania to } \\
\text { Greece }\end{array}$ & 1,300 & -33.13 & $\begin{array}{l}\text { Albania: } 1,192 \\
\text { Iraq: } 6 \\
\text { Cuba: } 5 \\
\text { North Macedonia: } 4 \\
\text { India: } 3\end{array}$ \\
\hline $\begin{array}{l}\text { 7. Eastern Land } \\
\text { Borders }\end{array}$ & 590 & -18.28 & $\begin{array}{l}\text { Russia: } 100 \\
\text { Turkey: } 59 \\
\text { Ukraine: } 48 \\
\text { Bangladesh: } 44 \\
\text { Afghanistan: } 40\end{array}$ \\
\hline Sum for 2020 & 123,803 & $-12,72$ & $\begin{array}{l}\text { Syria: } 17.3 \text { percent } \\
\text { Morocco: } 16.7 \text { percent } \\
\text { Algeria: } 10.6 \text { percent } \\
\text { Tunisia: } 10.5 \text { percent } \\
\text { Afghanistan: } 8.1 \text { percent }\end{array}$ \\
\hline
\end{tabular}

1 According to Frontex terminology, these are "illegal" border crossings. IOM, on the other hand, uses the term "irregular" instead when talking about migrants. This term also expresses that the legal status can change when the need for protection is recognized (Protocol against the Smuggling of Migrants by Land, Sea and Air, supplementing the United Nations Convention against Transnational Organized Crime, (adopted 15 November 2000, entered into force 28 January 2004) 2241 UNTS 507) Art. 3(a). I therefore use the term "irregular migrants" or "illegal border crossings".

2 Both maps are reprinted with kind permission of Frontex, the European Border and Coast Guard Agency.

3 Data for table 1 taken from https://frontex.europa.eu/along-eu-borders/ migratory-map/, retrieved at 10. February 2021. The comparative figures from 2019 are from the previously mentioned Frontex Risk Analysis Map (Map 2). I added the percentage change and bottom sum line and calculated the sum top 5 countries using the Excel spreadsheet provided on the website, ignoring unspecified nationalities in the last line.
Table 1 highlights the importance of maritime routes as part of the migratory situation and how the usage of the different routes changed from 2019 to 2020. In 2020, a sharp rise of crossings on the Central Mediterranean route moved it up to the first place with more than 35,000 crossings in comparison to only about 14,000 in 2019. This represents a rise of almost 155 percent. Another shift can be seen in the direction of the Western Balkan route with a rise from more than 15,000 crossings in 2019 to almost 27,000 in 2020 which brings the route to second place with an increase of almost 78 percent. The Western African route gained unpreceded popularity and has an even sharper increase from less than 3,000 to more than 22,000 irregular crossings, which represents an increase of more than 730 percent at third place. The Eastern Mediterranean Route is down to fourth place with nearly 20,000 irregular border crossings and a reduction of more than three quarters. The Western Mediterranean route moved to fifth place in 2020 with a drop from almost 24,000 to about 17,000 crossings, which represents a decline of almost 29 percent To sum up, the overall numbers dropped slightly in 2020 (from 141,846 to 123,803). This is a drop of just under 13 percent. For the number of irregular border crossings, we thus have the lowest value in seven years.

The UN Refugee Agency counts the arrivals slightly different than Frontex, but also states a decrease of arrivals in Europe. For the sea arrivals in Europe via the Mediterranean and the Canary Island routes they estimate a 23 percent decrease in 2020 compared to 2019. Here the Canary Island routes seems to be similar what Frontex calls the Western African routes. They similarly note a significant variation of the routes to the year before. They point out that at the same time the arrivals in Italy almost tripled. Whereas in Spain the arrivals to the mainland decreased, they also point out like Frontex, the increase for the Canary Islands (UNHCR 10.02.2021).

Two reasons are highlighted for the developments: "While States generally preserved access to territory for people seeking international protection, an increasing number of credible reports about pushbacks at European borders, as well as some States' invocation of Covid-19 prevention measures to limit access to territory, affected the arrival and movement of asylumseekers and refugees" (UNHCR 10.02.2021). The UNHCR points to the continuously decreasing numbers of arrivals and raises the question of why Europe still fails to show solidarity for them since it can hardly be assumed that the capacity of the receiving facilities all over Europe is too low for these numbers (Tagesschau 28.01.2021)

If we measure the success of EU border protection in terms of the number of arrivals or irregular border crossings, it seems to be successful. This seeming success story is undermined when we measure migration policies in terms of successful rescues.

Let us therefore turn to the number of dead and missing persons at sea, as provided by the UNHCR, also known as the UN Refugee Agency. They led to a rigorous critique of Europe's response. The accusation is that the EU has accepted the death of many migrants in order to protect its borders. The trigger for this accusation was a steep rise in the number of dead and missing persons from 2013 onwards. Only in 2019 did the numbers fall under the threshold of 2,000 people. However, this does not include thousands of people who disappeared on 
land after being returned by the Libyan coast guard. If we start from UNHCR figures, the number of arrivals has decreased by 90.8 percent from its peak in 2015 to 2020 . The number of dead or missing persons in the Mediterranean Sea has only reduced by 69.6 percent in the same period with almost 20,300 people dead or missing estimated in the period 2014-2020 (see table 2).

Table 2: Arrivals compared to Dead and Missing Persons for the Mediterranean Sea (estimates by UNHCR) ${ }^{4}$

\begin{tabular}{|l|l|l|l|l|}
\hline Previous years & Arrivals & $\begin{array}{l}\text { Percentage } \\
\text { change }\end{array}$ & $\begin{array}{l}\text { Dead and } \\
\text { missing }\end{array}$ & $\begin{array}{l}\text { Percentage } \\
\text { change }\end{array}$ \\
\hline 2020 & 94,950 & -23.22 & 1146 & -14.16 \\
\hline 2019 & 123,663 & -12.59 & 1335 & -41.19 \\
\hline 2018 & 141,472 & -23.59 & 2270 & $-27,68$ \\
\hline 2017 & 185,139 & -50.45 & 3139 & -38.40 \\
\hline 2016 & 373,652 & -63.81 & 5,096 & +35.14 \\
\hline 2015 & $1,032,408$ & +357.93 & 3,771 & +6.59 \\
\hline 2014 & 225,455 & +275.76 & 3,538 & +489.67 \\
\hline 2013 (estimates) & 60,000 & - & 600 & - \\
\hline
\end{tabular}

Are the critics right? Has this been a shameful failure of European sea rescue? Have we failed to send sufficient rescue ships and to open our ports?

\subsection{EU Maritime Operations: Successes and Decline}

By describing the developments of EU maritime operations, this article demonstrates the national and European missions and elaborate operations, which were always accompanied by criticism, but have long been successful in maritime rescue before the political consensus collapsed and the EU and its members relied more and more towards the externalization of border controls. The timeline of the EU maritime operations in the Mediterranean (see figure 1) shows that almost 539,000 lives were saved by EU missions since 2015 in the whole area of the Mediterranean according to EU data (Council of the European Union 05.03.2021).

This timeline traces the development of EU maritime operations in the Mediterranean. The top part of the timeline indicates operations, and the bottom part indicates other influential events.

In 2013, numerous shipping accidents, in which several hundred people died, led to the launch of the Italian operation "Mare Nostrum". Italy complained of unfair burden-sharing in securing the EU's external borders. After Mare Nostrum's suspension, Frontex took over in 2014 with Operation Triton. Following strong criticism of the limited budget and mission, Triton was extended in a second mandate.

In 2015, EUNAVFOR Operation Sophia was initiated. There was also a temporary opening of external EU land borders. After more than 1 million people entered the EU during that time, the land borders and the Balkan route were largely closed again.

In 2016, the EU-Turkey deal ensured that Turkey would handle the arriving migrants. The Frontex Operation Poseidon supports Turkish and Greek Coast Guards in sea rescue. The rescued migrants are then usually brought back to Turkey.

For migrants who cross via the Western Mediterranean instead, Spanish authorities are supported by Frontex Operation Indalo, initiated in 2017.

In Triton's successor operation since 2018, Themis, ships have been patrolling rarely in the Central Mediterranean. Triton and Themis have rescued more than 264,000 people.

In the summer of 2018, Italy's Interior Minister Matteo Salvini (of the right-wing "Lega" party) largely closed its ports to NGO rescue ships (Cusumano and Gombeer 2020). The previously

\section{Figure 1: Timeline of the EU Maritime Operations in the Mediterranean ${ }^{5}$}

\begin{tabular}{|c|c|c|c|c|c|c|}
\hline $\begin{array}{l}\text { Mare Nostrum } \\
\text { (by Italy) } \\
\text { Oct. } 2013 \text { - Oct. } 2014 \\
120,000 \text { rescued } \\
\text { Frontex Operation } \\
\text { Triton I+II } \\
\text { (Italy) } \\
\text { Nov. } 2014 \text { - Jan. } 2018\end{array}$ & $\begin{array}{l}\text { EUNAVFOR Med } \\
\text { Operation Sophia } \\
\text { June } 2015 \text { - } \\
\text { March } 2020 \\
45,000 \text { rescued }\end{array}$ & $\begin{array}{l}\text { Frontex Operation } \\
\text { Poseidon } \\
\text { (Greece) } \\
\text { Jan. } 2016 \text { (ongoing) } \\
129,000 \text { rescued }\end{array}$ & $\begin{array}{l}\text { Frontex } \\
\text { Operation Indalo } \\
\text { May } 2017 \text { (ongoing) } \\
\text { (Spain) } \\
98,000 \text { rescued }\end{array}$ & $\begin{array}{l}\text { Frontex Operation } \\
\text { Themis } \\
\text { (Italy) } \\
\text { Feb. } 2018 \text { (ongoing) } \\
\text { (follow-up of Triton) } \\
\text { all: } 267,000 \text { rescued }\end{array}$ & & $\begin{array}{l}\text { EUNAVFOR Med } \\
\text { Operation Sophia } \\
\text { March } 2019 \text { - } \\
\text { March } 2020 \\
\text { Naval assets terminated } \\
\text { EUNAVFOR Med IRINI } \\
\text { March } 2020 \text { (ongoing) } \\
\text { No rescues }\end{array}$ \\
\hline 2014 & 2015 & 2016 & 2 & 2018 & 2019 & \\
\hline & $\begin{array}{l}\text { Opening of } \\
\text { external EU land } \\
\text { borders } \\
\text { Dublin regulation } \\
\text { suspended; } \\
\text { nat. border controls } \\
\text { reintroduced }\end{array}$ & $\begin{array}{l}\text { Near total closure } \\
\text { of the Balkan } \\
\text { route } \\
\text { March } 2016 \\
\text { EU-Turkey Deal }\end{array}$ & & & $\begin{array}{l}\text { Criminalization of } \\
\text { private rescuers }\end{array}$ & $\begin{array}{l}\text { Italy and Malta } \\
\text { close ports } \\
\text { due to Covid-19 } \\
\text { EU-Turkey Deal } \\
\text { in crisis }\end{array}$ \\
\hline
\end{tabular}

4 "Include sea arrivals to Italy, Cyprus, and Malta, and both sea and land arrivals to Greece and Spain (including the Canary Islands). Data are as of 31 December 2020 for all countries except Cyprus for which last available data are as of 31 August 2020", data from UNHCR (10.02.2021). Comparative figures from 2013 also from UNHCR by McKinsey (2014). I added the percentage changes.

5 Author's illustration; data of missions: Council of the European Union (05.03.2021) 
successful collaboration between aid organizations and Italian authorities has come to an end at that point in time.

In 2019 , the attempt to criminalize private actors continued to discredit them as collaborators with smugglers and their ships were confiscated (Oellers-Frahm 2019). All legal means were used to obstruct civilian rescue missions. These included bans on departures, ongoing investigations, charges of improper waste disposal, arbitrary flag removal, etc. Although no wrongdoing could be proven in court, public trust in aid organizations was damaged (Funke 2018). Italy took the view that a distribution key for migrants to other European countries should be guaranteed in advance for each individual ship. This led to week-long waiting times, imposing unreasonable burdens on rescued persons and crews. It also revealed deep rifts within the EU (see section 4.1).

At the same time, EUNAVFOR Med Sophia was downgraded to a mission without ships. Since then, it has only been responsible for monitoring airspace and training the Libyan Coast Guard. For months, the Italian Naval Command deployed navy ships to areas that were far away from the main routes. For this reason, the German government decided as early as January 2019 to suspend the participation of German ships. The EU has been unable to reach an agreement on reviving the naval mission. This was also due to resistance from the nationalistic governments of Poland and Hungary.

In March 2020, EUNAVFOR Med Irini was established with its primary task to implement the UN arms embargo for Libya. However, two of the secondary tasks relate to sea rescue: capacity building and training for the Libyan Coast Guard and Navy as well as the contributing to the disruption of the business model of human smuggling and trafficking networks. A special feature is the unprecedented control over the deployment by member states, which have the option of initiating a decision procedure which will terminate the entire operation or would lead to not extending the mandate in the event of a perceived pull effect on migration. This illustrates how much care was taken to ensure that this mission was not a follow-up to EUNAVFOR Med Sophia. EUNAVFOR Med
Irini was involved in the (onward) reporting to other authorities and monitoring of maritime emergencies, but there is no indication that people were rescued directly. The ships are deployed away from the migration routes. Mainly because arms shipments are still flourishing, the mission has so far been deemed less than effective (Deutscher Bundestag 03.02.2021; Pietz and Ladewig 22.03.2021).

In 2020, the overall situation worsened further. The EU-Turkey Deal was temporarily called off by Turkey, which resulted in mass movements at the land borders. The deal is set to be renegotiated (see (Adar, Angenendt, Asseburg, Bossong, and Kipp 03.2020). Since the outbreak of Covid-19 in Europe, Italy and Malta have taken the opportunity to implement public health measures to further (temporarily) restrict the entry of migrants. In addition, the EU has been unable to reach an agreement on reviving the sea rescue mission.

What remains is an impressive number of rescues. The EU operations saved more than 539,000 lives since 2015 in the whole area of the Mediterranean, at the same time more than 12,000 people were estimated dead or missing (Council of the European Union 05.03.2021) in that time period. However, most naval missions that had sea rescue in their mandate stopped. It is reasonable to assume that the decline in maritime operations may result in more deaths.

This concludes a brief overview of EU maritime operations. I would now like to draw your attention to the area of the Central Mediterranean in particular. The crossings here comprise the most life-threatening routes, the most dangerous waters for migrants. The lack of rescues at sea in this area have therefore received the most criticism.

\subsection{Private and Other Actors Performing Rescues in the Central Mediterranean}

Who was performing rescues in the Central Mediterranean? In sum, various actors have participated in rescue operations. 522,621 persons were saved in the Central Mediterranean by

Figure 2: Who was performing rescues in the Central Mediterranean? ${ }^{6}$

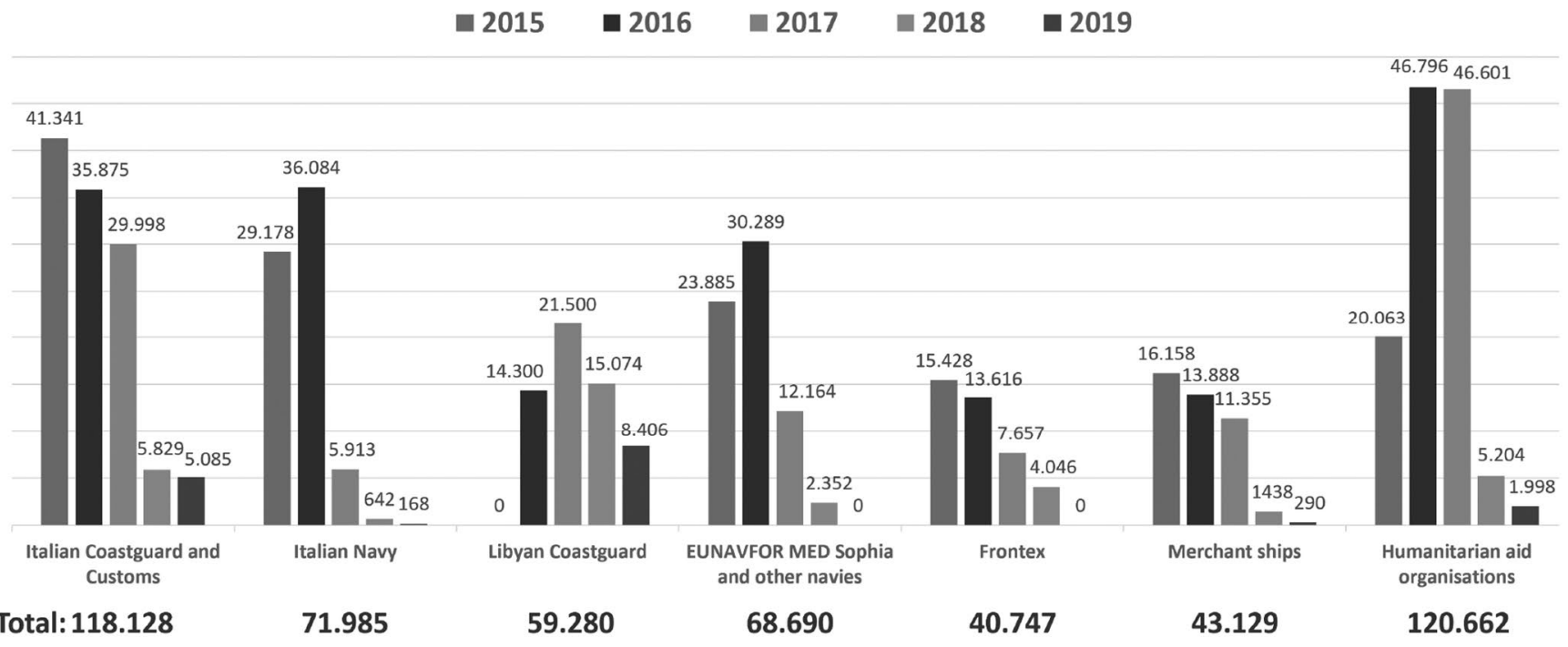


the various actors in 2015-2019 (sum of figure 2). Figure 2 also shows the strong decline of sea rescue missions over time.

It is not surprising that the Italian authorities and navy played a leading role in rescuing migrants in their territorial waters and their Search and Rescue Zone in 2015-2017. EU NAVFOR Med Sophia and Frontex also contributed considerable in 2015-2017 (see figure 2). There is the accusation that aerial reconnaissance is recently partly outsourced to private contractors so that Frontex does not "officially" become aware of the maritime emergencies and is obliged to act, see (Howden, Fotiadis, and Campbell 12.03.2020; Monroy 12.06.2020) and on the situation in the waters of Malta the report of Amnesty International (07.09.2020).

Let us turn to private actors. Merchant ships rescued slightly more people than Frontex. Due to a rising number of ships not capable of travelling off the coast experiencing an emergency, humanitarian aid organizations sent their own ships, starting in 2015. From 2016 there was an increase in rescue ships and aid organizations. These included "Sea-Watch", "Doctors without Borders / Médecins Sans Frontières" and "Save the Children". This contributed considerably to decreasing the number of dead and missing migrants. Since Italy largely closed its ports to NGO rescue ships, private rescuers have now resumed rescues on a much smaller scale. "The existence of civil sea rescue is a visible sign that Europe is not fulfilling its obligation to save these people", stated Heinrich Bedford-Strohm from the German Protestant Church who did the fundraising for the ship Sea Watch 4 (ARD 29.03.2021).

\subsection{The Libyan Coast Guard: Cutting off the Sea Route}

Since June 2017, Libya has taken over responsibility for the Search and Rescue (SAR) zone from Italy. In terms of coordination, equipment, surveillance and training, it is supported by Italy on behalf of the EU or EU authorities. The criticism is that the EU is deliberately sharing aerial reconnaissance with the Libyans and that rescues by European state ships or warships are being actively withheld at the same time. This explains why the rescue numbers of the Libyan Coast Guard have increased while those of Italy decreased and European Naval Forces and Frontex have no rescues at all in 2020 (see figure 2). In purely legal terms, other foreign sea rescue units may continue to carry out humanitarian activities in case of an emergency within the Libyan SAR zone. This is emphasized in an expert opinion by the Scientific Services of the German Bundestag (Wissenschaftlieche Dienste Deutscher Bundestag 25.08.2017).

In the Central Mediterranean, the trend toward outsourcing border management is therefore manifested in the cooperation established with the Libyan Coastguard. Both EU operations and humanitarian aid organizations have been replaced by the Libyan Coast Guard, which - on the one hand - rescues and deters.

On the other hand, when people are rescued, they must be taken to a "place of safety" as quickly as possible. This is the wording in the

6 Author's illustration. Data from Mediendienst Integration (08.02.2021). Currently there is no source on the different rescuers operating in the Mediterranean for 2020, as the main source of this data, the Italian Maritime Rescue Coordination Center MRCC, stopped publishing this data in 2019 . This was confirmed via e-mail by the International Organization for Migration (IOM) on 16 February 2021.
International Convention for the Safety of Life at Sea (SOLAS, 1.1) and the current Manual of the International Maritime Organization (IMO). ${ }^{7}$ In addition, individual asylum requests must be assessed in fair procedures. European states and therefore European ships are bound by the Geneva Convention on Refugees, the Convention against Torture and the European Convention on Human Rights. That's why for them Libya cannot be regarded as a safe place, as migrants who are taken there are threatened with serious human rights violations and repatriation to states where they will be persecuted (see the discussion on non-refoulement and push-backs in section 3.2). Criticism of the cooperation with the Libyan Coast Guard is also fueled by the fact that there are reports on several cases of excessive use of violence by the Libyan Coast Guard.

Liguori (2019:v). states that "multiple arrangements with unsafe third countries, exposing migrants and asylum seekers to serious human rights violations ... [belong to a policy of] externalizing border control risks creating 'legal black holes'”. One way to fight 'legal black holes' is to seek legal interpretation of international courts. For example, lawsuits were filed against Italy with the European Court of Human Rights for aiding human rights violations in Libya as (Bendiek and Bossong 08.2019) pointed out.

The transfer of responsibility for sea rescues as a means of externalization of EU borders to the Libyan Coast Guard has allowed for the successful circumvention of the ban on refoulement. Nevertheless, the limits of legality could be transgressed by certain practices such as push-back operations.

\section{Sea Rescue of Migrants: Obligation to Rescue or Right to Refuse?}

Rescue at sea in the Mediterranean remains controversial because of the controversial nature of maritime emergencies of migrants. In addition, key terms like "fortress Europe" vs. "open doors" and policies of border externalization are fiercely debated.

\subsection{The Controversial Nature of these Types of Maritime Emergencies}

Rescue at sea has several features of a classic maritime emergency but also differs in several respects (see figure 3).

7 "REALIZING the need for clarification of existing procedures to guarantee that persons rescued at sea will be provided a place of safety regardless of their nationality, status or the circumstances in which they are found [Preamble] (...)

A place of safety (as referred to in the Annex to the 1979 SAR Convention, paragraph 1.3.2) is a location where rescue operations are considered to terminate. It is also a place where the survivors' safety of life is no longer threatened and where their basic human needs (such as food, shelter and medical needs) can be met. Further, it is a place from which transportation arrangements can be made for the survivors' next or final destination. [6.12] (...)

The Refugee Convention's prohibition of expulsion or return "refoulement" contained in Article 33.1 prohibits Contracting States from expelling or returning a refugee to the frontiers of territories where his or her life or freedom would be threatened on account of the person's race, religion, nationality, membership of a particular social group or political opinion. Other relevant international law also contains prohibition on return to a place where there are substantial grounds for believing that the person would be in danger of being subjected to torture" (IMO MSC.167(78): IMO Maritime Safety Committee (adopted on 20 May 2004) 


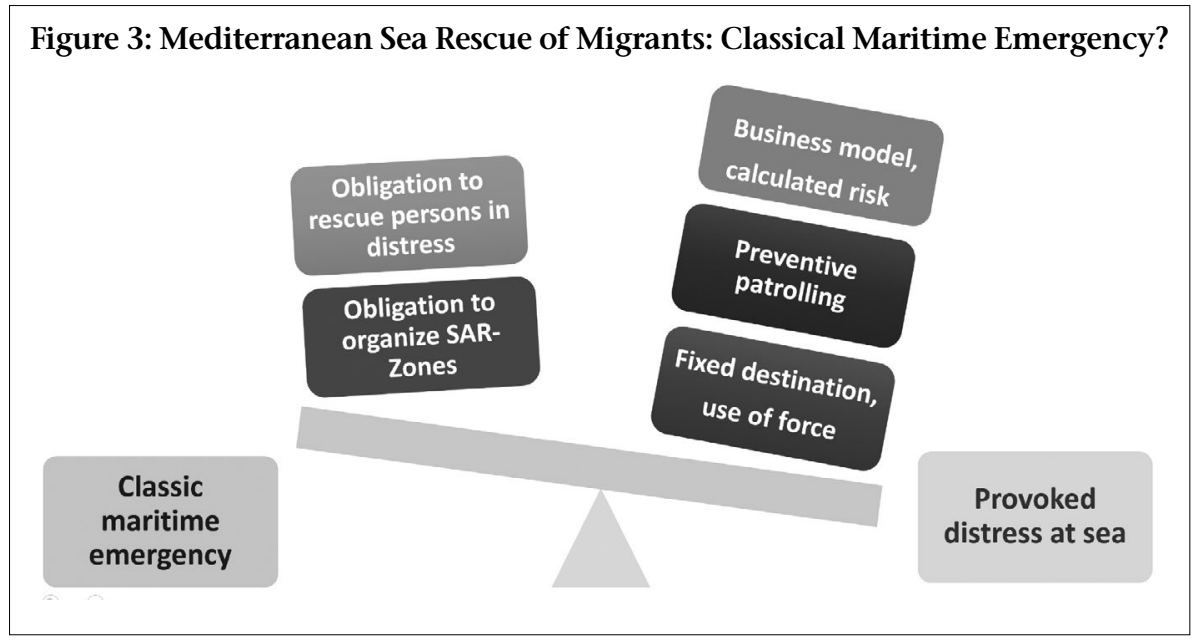

"Ocean Viking", migrants threatened to turn the violence against themselves, warning that they would kill themselves or go on a hunger strike (Deutsche Welle 03.07.2020).

From the above, it is clear that these are not maritime emergencies in its original sense, but rather situations of induced or provoked distress at sea. However, this also makes it predictable that sea rescue operations are necessary. The recent use of seaworthy fishing boats as hiding places for Sub-Saharan Africa migrants trying to cross from Tunisia, on the other hand, is much less controversial because it does not raise the legal and moral issues of sea rescue.
There is a legal obligation to rescue those in distress. Coastal states and regional partners also have an obligation to organize effective Search and Rescue (SAR) Zones. Both are outlined in the United Nations Convention for the Law of the Sea - UNCLOS. UNCLOS mentions collisions as a classic example, and thus the provisions were designed for unplanned accidents. Although there is a need to organize SAR Zones, there is no obligation to conduct preventive patrol missions in areas where accidents may occur.

The reality, however, is dominated by smugglers trafficking people who include sea rescue in their business model (Europol and Interpol 2016; Europol 2019). Their aim is to get as many people as possible on the cheapest boats possible (which are most often not seaworthy) in order to maximize their profits. Responsibility for thousands of missing persons is thus borne by the smugglers through their reckless behavior. The question remains whether or not a share of responsibility for the European migration and border policy can be attributed here. Even if some feel forced to: many desperate migrants take this calculated risk willingly, which makes this situation gravely different from unplanned maritime emergencies.

In some cases, people who are not yet in an emergency are taken on board. In such cases, however, one could argue that it is only a matter of time before disaster strikes the overcrowded boats. ${ }^{8}$

Most importantly, many of those who take these boat journeys have a fixed destination in mind, namely the European Union. When ships that want to bring them to Libya to rescue them, things can get violent as some people resist rescue. This also shows a clear difference to classic sea rescue. The difference is also made clear by the fact that the Libyan Coast Guard has used force against migrants who do not want to come aboard. There are reports on several cases of excessive use of violence by the Libyan Coast Guard.

On the other hand, in one case, migrants forced a merchant crew of a tanker to bring them to Europe (BBC News 28.03.2019). In another case, migrants threatened to set a Maltese quarantine vessel on fire (Deutsche Welle 07.06.2020). In the case of the

8 "There is no international treaty or customary law definition of distress at sea. In general, however, is considered to be distress at sea if there is reason to believe that a ship and the persons on it will not be able to reach safety without outside help and will be lost at sea. This includes a ship that is unable to maneuver, a lack of rescue equipment, overcrowding endangering the health of the passengers or the safety of the ship, or inadequate provision of food, drinking water or necessary medication" (Deutscher Bundestag August 25th, 2017:6, translated).

\subsection{Fortress Europe, Open Doors, Border Externalization}

The protection of external borders is often perceived as a "Fortress Europe" policy. By contrast, opening borders to migrants and enabling them to exercise their right to claim asylum is often associated with an "open door policy". It is important to clarify for the debate that while migrants have the right to leave their country, there is no right to enter another one. States are free to decide whom they let in. In the case of Europe's external borders, a shared responsibility is also at work. The Schengen Agreement, for example, made it possible to have free movement within Europe as long as external borders were secured. National border controls have been partly reintroduced, however.

One argument that is made against fully opening borders is that the "interests of prospective migrants must be weighed against the interest of the political community" (Song 2018: abstract). Opening the borders for migrants therefore remains a sovereign, voluntary decision and a weighing of the state's own (or the EU's common) resources and political consensus. This is on the condition that no illegal practices of deterrence (at sea) are used and that the right is preserved for those who cross the border to be given a fair asylum procedure.

In this logic, an unfair trade policy cannot be compensated by bearing the consequential costs of receiving (maritime) migrants in unlimited quantity, because the adequate social provision of EU citizens often cannot be guaranteed either (Riedel 2020:43-44).

The relevance of establishing better migration policies can also be framed in terms of the migration-security nexus and the migration-peace nexus. The migration-security nexus refers to the dangers of crime and terrorism (Schneider 2016). A necessity of controlling persons entering the EU via land or sea is thus evident. However, it also reveals the problem of right-wing violence against politicians and journalists who are in favor of migration.

The peace-migration nexus highlights the opportunities for the labor market and for social inclusion in the host society. It also demonstrates the potential role that migrants can play in the social and political transformation of their home countries (à propos 2020). Many civilian actors stress these aspects and create initiatives 
for the reception and integration of migrants. One example is the "Cities of Safe Harbours" ("Seebrücke") initiative, who lobby for an easier relocation of rescued migrants from the Mediterranean to cities who provide voluntary resettlement schemes. So far, however, this has largely failed due to the refusal of governments of European nations.

Various actors - including migrant, humanitarian aid and human rights organizations, churches, and parties - have lobbied for the generous opening of borders. They make use of concepts like non-refoulement and neo-refoulement and post-colonialism. This illustrates how we can classify the same facts in very different ways through different world views and theoretical concepts (see section 4.1).

Various conventions oblige European Union member states to assess asylum claims via fair procedures. Non-refoulement, according to the UNHCR, gradually acquires the character of a fundamental norm which permits no derogation (UNHCR 26.01.2007:8). However, it results in a protection gap. The gap arises when no push-backs are allowed, but only for those who are able to enter. Just how states who block migrants can be held accountable is a controversial matter. State sovereignty seems to clash with human rights protection.

In addition, there are reports that push-backs still occur, for example between the Croatian/Bosnian border and the Greek/Turkish border. So far, it has not been possible to dispel all allegations against Frontex in this regard (Heflik 06.03.2021). Push-backs to Turkey are criticized for three reasons: For endangering migrants when they are abandoned on unmaneuverable boats or inflatable life rafts in Turkish waters (Spiegel Online 24.03.2021); because Turkey is not considered as a safe third country and/or because Turkey carries out "indirect or chain-refoulements [to other countries, which] are also prohibited by international law" (Buddelmann and Graf 08.12.2020).

\subsection{Failure to Rescue or Legitimate Border Closure/Externalization?}

An indicator of the success of the EU operations is the high number of people rescued in the Central Mediterranean with more than 100,000 people rescued (of more than 522,000). Almost 539,000 lives were saved by EU missions since 2015 in the whole area of the Mediterranean. The number of saved people points to the humanitarian need for EU missions.

With that said, it must be noted that we see a reduced number of arrivals in Europe. We can observe that the number of dead and missing persons has decreased together with the general arrival figures via the maritime routes. Thus, the deterrence policy and the externalization policy of the EU border controls have also contributed to a reduction in the number of dead and missing persons in the Mediterranean Sea. However, this number has declined on a smaller scale, and it is plausible to assume that the mortality rate would be lower if EU missions continued to contribute to sea rescue.

I therefore argue that European States fail to perform their obligations of rescue, though effectively leading to a decline of arrivals. Under these conditions they do not reflect legitimate and legal border externalization.

In addition, the causes of flight have not been sufficiently addressed - including poverty and civil war. Therefore, the number of arrivals at sea and land borders could easily rise again. This means that European countries are likely to continue to face a fluctuating number of arrivals that is more or less unaffected by actual sea rescue operations.

The initially fruitful cooperation with humanitarian aid organizations and their high rate of rescues was replaced by the criminalization and disabling of this assistance after change of government in Italy (Funke 2018a; Reinke de Buitrago and Schneider 2020). Regardless of the controversial nature of these types of maritime emergencies, even if we establish that they are rather provoked or (self-)induced cases of distress at sea and smuggling networks should be disrupted, the obligation to rescue and bring the migrants to a safe place persists. Private rescuers should therefore be re-engaged in migration governance not as a threat, but as part of the solution.

\section{Policy Challenges}

The breathing space that has been created by fewer arrivals should be used to tackle the challenges of European migration policy. But why is this so difficult?

\subsection{Three Dilemmas of EU Migration Policies}

I have selected three dilemmas in EU migration policy that help to explain why it is so challenging to establish an effective responsibility sharing system even in times of low number of arrivals, and why these dilemmas are of importance for sea rescue and border externalization as part of the European migration policies (see figure 4).

The Cambridge Dictionary defines a dilemma as "a situation in which a difficult choice has to be made between two different things you could do" (Cambridge Dictionary 10.02.2021). The first dilemma represents the difficult choice between the protection of external borders vs. granting asylum seekers access. The ship in this figure symbolizes the rescue missions. The second dilemma deals with the North-South divide within the EU. The arrows pointing in different directions symbolize the North-South (and East-West) divide. The third dilemma concerns two diverging aims pursued by member states: deepening and division. The target logo symbolizes this.

\section{Dilemma 1: Protection of External Borders vs. Asylum}

Different schools of thought in political science explain the decisions by different actors regarding the prioritization of protection of external borders in relation to sea rescue. National or European security can be defined as an exercise of control by the state(s) or EU authorities to protect sovereignty, especially territorial integrity. It prioritizes the protection of the well-being of legal residents. In contrast, human security is concerned with ensuring that all people - including irregular migrants - are 


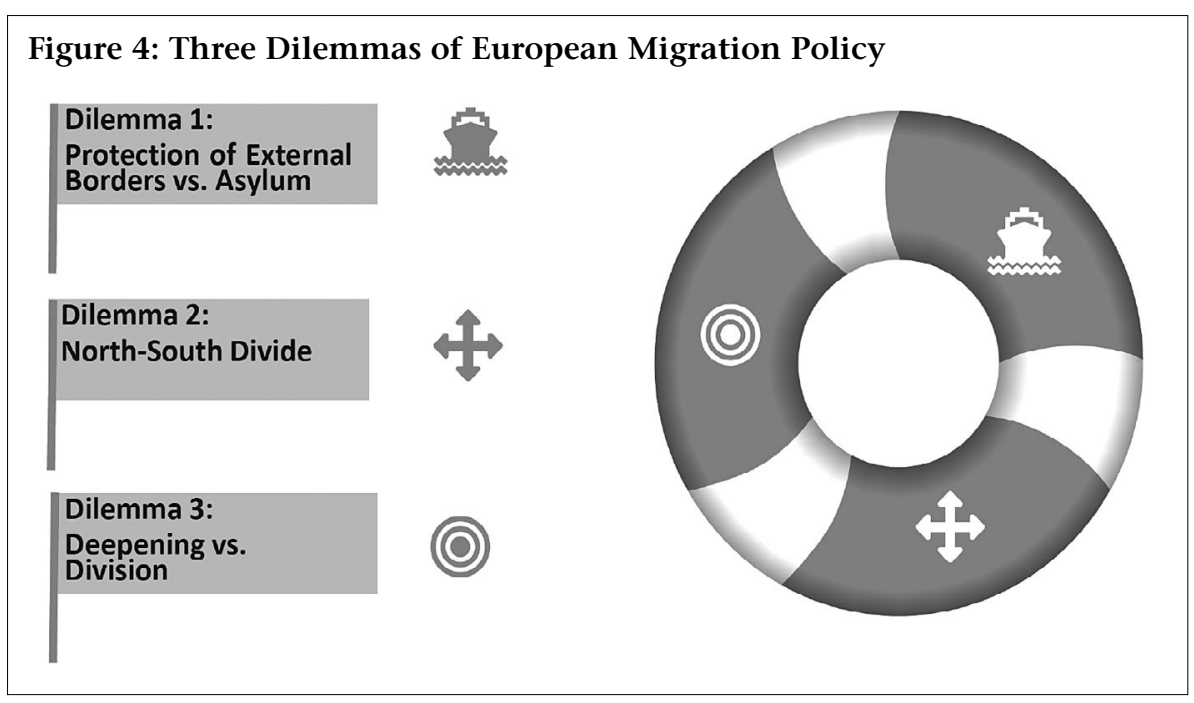

free from want and fear. This includes freedom from hunger, fear of violence and injustice. From this perspective you would argue for a strict welcoming policy including prioritizing sea rescues or full opening of borders. The legalization of entry would make dangerous trips at sea unnecessary.

Through the lens of realism, the protection of sovereign borders, especially the reintroduction of national border controls in the Schengen area or bilateral agreements of member states with third state actors to externalize border controls, can be viewed as a power game between EU states. The different decisions made by states are explained by appealing to the different perceptions of their leaders, strategic cultures, state-society relations, and the like (Ripsman, Taliaferro, and Lobell 2016).

Security Governance instead emphasizes the need to reach a common understanding of a problem (here: migration) shared by different actors (here: different EU states) in order to regulate and manage the problem via cooperation (for example via the Frontex Agency or Europol to combat human smuggling) (for the conceptual building blocks of security governance see Ehrhart 2013). Followers of this approach would seek ways to optimize the cooperation of $\mathrm{EU}$, state and non-state actors to manage migration according to the current Dublin Regulation including functioning sea rescue until a different political consensus can be reached.

The concept of securitization is part of the theory of constructivism. Migrants are socially constructed as a threat by certain parts of society that justifies extraordinary measures. Restrictive and deterrent measures are framed as an inevitable policy response. The externalization of border controls, the increase in funding for Frontex and the cooperation with third states is often criticized as unnecessary securitization of the phenomenon of migration.

By contrast, the concept of neo-refoulement speaks in favor of a right to enter. It draws from post-colonial theory. Immigration and border regimes are perceived as products of colonialism and hegemony. The core of the problem for these thinkers is a refusal to share "'imperially acquired' wealth and resources" (Odwyer 29.08.2018), as they call it. Another root of the problem from this perspective is the exploitation of poorer, dependent states in border externalization regimes, which treat migrants as a commodity. They urge powerful Western states to revisit their core values so as to preserve their normative power. Migrants' perspectives and a migrant agency should be included in policy-making (Hirsch and Bell 2017; Fitzgerald 2019). Let us now turn to the second dilemma.

\section{Dilemma 2: North-South Divide}

The frontline states with sea borders that are most affected are Italy, Malta, Spain and Greece, they also receive the most migrants via maritime routes. If they decline disembarkation, this heavily inflicts with sea rescue. When it comes to land borders, the most affected states are south-eastern European countries.

Frontline states have demanded the solidarity of the other EU members. Where they have felt that support has been lacking, this has resulted in the closure of ports or cooperation with coast guards of third states like Libya and Morocco.

The Dublin Regulation lacks legitimacy because it seems unfair that asylum seekers are allocated to the states for first entry. This system also sets incentives for a "race to the bottom regarding asylum standards (...), incentives for becoming less welcoming" (Parusel 2020:68-69) to deter migrants.

With reference to the Dublin Regulation, states can refuse to implement reforms that would make them more accountable. Northern states have the geographical advantage that migrants are unable to reach them without first passing through another EU country that is classified as safe. On the other hand, it is not uncommon that tacit support is given when migrants travel on to other EU countries, which again leads to conflicts.

Northern states can execute a form of burden sharing with southern states also via their voluntary humanitarian visas and resettlement programs. So far, the scale of these programs remains relatively small because of the fear to attract more migration (Parusel 2020:46,69).

Northern states may also face different security issues or have other priorities, such as perceived threats from Russia. At the same time, they have contributed to the expansion of Frontex and cooperation with third states.

For many years, scenarios have been discussed to reform the Dublin system of responsibility sharing. Instead, we see trends of re-nationalization with unilateral approaches, bilateral agreements and push-backs into third countries. The status quo is characterized by an ad-hoc mode for relocation after disembarkation which continuously sets incentives to deter migrants and keeps arrivals longer on the ships. Currently, there is an attempt to improve this to a mode of flexible solidarity, meaning that the Dublin Regulation is complemented by expressing solidarity in other ways than relocation such as financial compensation, contributing to capacity building or returns. Presumably, however, this will not end the debates about state solidarity and responsibility sharing and a system of fair quotas (Parusel 2020:70-72).

\section{Dilemma 3: Deepening vs. Division}

The third dilemma concerns the tension between deepening and division. The more typical pair of opposites is actually 
deepening and widening as two directions for EU development. Deepening refers to the increased integration of the EU, one example of which is the single currency, the Euro. An effective migration management system - including a disembarkation mechanism, fair relocation quotas and common standards for asylum procedures - would also present a deepening of the EU. Proponents of widening seek a looser EU with more members. There has not been much lobbying for further enlargement. The last enlargement took place with Croatia's accession in 2013. Since the exit of the United Kingdom in January 2020, 27 members remain. Instead, the EU has been struggling with internal rifts and has been shifting between deepening and division.

Enhancing common asylum policies would deepen the EU. Why actors support or do not support the evolution of the EU towards integration can be explained, for instance, by case studies that use concepts from political science.

Why is it difficult to pressure non-compliant states into the previously agreed relocation mechanism although only comparatively small numbers of people were at issue? Institutionalism and regime theory views states as existing in a world of complex interdependencies. They stress that the configuration of institutions matters. The process of institutionalization should lead to greater cooperation. Non-compliance can be costly (Schneiker 2017:29-33). However, the lack of implementation of agreed-upon EU migration policies such as the distribution of migrants has shown that there are very few mechanisms in place to force states into implementation. Cooperation in areas that affect the sovereignty of states seems particularly difficult at the EU level and has an impact on the efficiency of EU migration governance. A possible 'carrot and stick' approach could make compliance a condition for receiving Corona help funds (to cope with the consequences of Covid-19), but the debates on budgetary issues like the Multiannual Financial Framework have shown that the criticized states can successfully block or decisively dilute targeted sanction mechanisms.

Modern Liberalism focuses on the influence of a society's democratic norms and values on the configuration of state preferences (Schneiker 2017:36). Different inner-state preferences can lead to the smallest common denominator at the EU level, as we have seen in common asylum policies. In addition, we have to take into account the fact that not all democracies are alike: established plural democracies may have strategies that differ from those favored by emerging or defective democracies.

Nationalism is often in tension with the strengthening of the EU. In addition, populism is on rise in many countries. It is perceived as an "illiberal turn" because populist governments prioritize protectionism and national interests. This presents a danger to the European Union as a community of norms and values. Populist parties usually exclude migrants from their identity politics and appeal to xenophobia, islamophobia and nativism, among others (Riedel 11. 2019:24). To become more resilient towards populist claims it could help "to build and maintain a cohesive national identity that can withstand minor shocks and risks from an outside, and that is still somewhat inclusive to newcomers - thus, to balance between cohesion and openness" (Reinke de Buitrago 2017:154).

Populists might have an interest in preventing an effective migration management system including disembarkation and relocation so that so that they can present dealing with incoming migrants not as a controllable governance issue, but as an existential threat to identity and resource distribution that will bring them more voters. Thus, every ship with rescued migrant people can become a sensitive political issue. This became all too clear when Italy's populist government temporarily blocked access to the port for ships carrying rescued migrants not only from private rescue vessels, but also from Frontex or its own coast guard.

These three dilemmas represent rifts within the EU and make it more difficult to govern migration, including issues of sea rescue and externalization of maritime border controls. If we view these dilemmas as knots, we can ask ourselves whether they are Gordian knots or sailing knots. A Gordian knot can only be untied by slicing through it with a sword or with an external shock. But if these dilemmas are best represented as sailing knots, then untying them requires diplomatic and technical skills.

\subsection{Possible Ways Forward}

What are the possible ways forward? The unresolved issues are evident.

Deeper EU cooperation requires a coherent migration governance system which goes beyond the Dublin Regulation. This could also include the expansion of Frontex (Bossong 12.2019) and Europol to protect borders and fight organized crime if complemented by human rights mechanisms. The protection of external borders is a legitimate task. Preventing crime includes establishing identities at borders, for example.

However, full compliance of EU agencies like Frontex with rule of law standards must be ensured to restore public trust. The European Parliament has increased pressure to clarify the allegations and hire fundamental rights watchdogs by refusing to approve the discharge of the 2019 budget from the European Border and Coast Guard Agency (Spiegel Online 24.03.2021). At the same time, it is necessary to pressure member states like Greece to stop illegal push-back activities. EU Commission President Ursula von der Leyen, however, has so far been rather known as supporter of the government in Athens, calling Greece "our protective shield" (Tagesschau 18.03.2021).

At ports, we need to have mechanisms ready for disembarkation and relocation. For common asylum procedures, we need EU standards for recognition and return policies. A Common EU Asylum Authority could contribute to "harmonizing and approximating national asylum decisions and procedures... [and function as well as] oversight and possible enforcement" (Parusel 2020:73).

More legal ways into the EU without dangerous trips can be established by increasing regulated resettlement from UNHCR refugee camps, for example via the issuing of humanitarian visas and resettlement. Several EU members increased their national resettlement quotas in recent years. Germany, for example, voluntarily takes about 5,500 people each year. The EU Commission lists commitments by EU states for the resettlement of almost 30,000 people for humanitarian reasons in 2020 (European Commission 23.09.2020b). Since these numbers are quite small given the needs in overcrowded refugee camps, we should also 
make use of the offers of communities to voluntarily host migrants as a way out of the deadlock. One example is the "Cities of Safe Harbours" ("Seebrücke") initiative. Parusel points out that irregular border crossings are "despite the enormous risks and dangers for those who undertake the journey, still a more realistic way of getting to stay in Europe than waiting for one of the still relatively few resettlement spots on offer" (Parusel 2020:44).

IOM and UNHCR recently called again for the resumption of rescue operations in the Mediterranean (Tagesschau 20.01.2021). EU Operations such as naval missions should be revived. If this is not possible, then at least the Frontex missions should resume rescuing migrants in the Central Mediterranean.

Humanitarian aid organizations are still willing to fill the gap and should be supported. Moreover, according to the motto 'nothing about migrants without migrants', we should ensure their agency/ ownership and participation in the debates. Humanitarian aid organizations can contribute to this by being cultural mediators, collecting testimonies and having a positive impact on the overall discourse as outlined by Funke (2021, forthcoming).

If the main goal of sea rescue is to save human lives, then sea rescue does not necessarily mean an asylum procedure in Europe. As cooperation with third actors can be expected to continue, one focus could be better surveillance of the Libyan Coast Guard, for example through the use of body cameras, to prevent excessive use of violence. The UNHCR should monitor the return of migrants to safe UNHCR camps. However, there are no indications that this can be realized in the near future. The government-run camps remain life-threatening detention facilities. The fact remains that Libya cannot be classified as a safe place. Illegal push-back actions at sea or on land should be strongly opposed and not given the impression of approval. Cameras for the Libyan Coast Guard as well as for Frontex missions could be helpful. Improving conditions in countries of origin and transit are also important goals.

Germany held two influential positions with Ursula von der Leyen as President of the European Commission, and the German Presidency of the Council of the European Union (01.07.31.12.2020). This created expectations for "ambitious reforms in asylum and migration policy", as announced in the program for Germany's Presidency of the Council of the European Union (Auswärtiges Amt 2020). However, the "New Pact on Migration and Asylum" (European Commission 23.09.2020a) does not embody an ambitious reform as many had hoped for, but complements the Dublin Regulation with a pragmatic flexible solidarity mode allowing member states to opt out of relocation. Though all member states are obliged to contribute, this does not necessarily include relocation for example after disembarkation but can also be done for example by sponsoring returns or operational support. Legal pathways into the EU remain unclear in the pact and - regrettably - most existing externalization policies seem to be legitimized (Angenendt, Biehler, Bossong, Kipp, and Koch 09.2020; Carrera 09.2020). "[T] he system proposed by the Commission is very complex, its impacts are difficult to assess, and whether the European Parliament and the Member State[s] will agree on it remains to be seen" (Parusel 2020:76).

A coordinated EU approach is to be established according to the pact, but much remains vague. At least private actors should not be criminalized but included (European Commission 23.09.2020c).
Recently, the few active private sea rescuers seem to actually have little problems being allowed to access ports with rescued persons like the Ocean Viking (Tagesschau 07.02.2021; Spiegel Online 23.03.2021). Nevertheless, unexpectedly, proceedings have only just been opened against private rescue organizations like Iuventa in an Italian court, accusing them of aiding and abetting illegal immigration (Iuventa 10 04.03.2021). Therefore, it seems that the criminalization is far from over. At the same time, organizations such as Sea-Watch are trying to defend themselves against what they see as politically motivated port state controls by Italy at the European Court of Justice (ECJ); the court case has not yet been decided (United4Rescue 16.02.2021).

The hope behind enforcement of returns is that if people who do not need protection actually leave the EU again, the willingness to establish a functioning asylum system might also be greater. However, due to the lack of economic prospects and ongoing crises, many people will continue to try to cross European borders regardless of the creation of seasonal worker visas and humanitarian visas and we need non-violent ways to deal with it. No consensus could be reached for a much needed far-reaching reform that goes beyond the Dublin Regulation to show solidarity with states as well as with individuals so far. It remains to be seen whether we can do this ("wir schaffen das") in the future and whether we can untie the knots or not.

\section{Conclusions}

The majority of migrants arriving in Europe via irregular border crossing were sea arrivals. This points to a high relevance of the issue of maritime migration and to a question whether we experience a failure of sea rescue in the Mediterranean or a successful externalization of borders.

The success of the EU operations consisted in the high number of people rescued in the Mediterranean. The deterrence policies and the externalization policy of the EU border controls on land and at sea have contributed to a considerable overall reduction in the number of arrivals as well as of the dead and missing persons in the Mediterranean Sea. However, the number of dead and missing has declined on a smaller scale, and it is plausible to assume that with the decline of these mission and the obstruction of private rescue efforts, the grave danger for the migrants' lives is relatively higher to cross the maritime borders today. The externalization of border controls in terms of sea rescue has further reduced the success because, on the one hand, the safe place for the rescued is not established in Libya and, on the other hand, the EU member states and Frontex are themselves involved in illegal push-back practices at Greek-Turkish maritime borders.

I therefore argue that these are, in fact, cases in which European States fail to perform their duties of rescue, though effectively leading to a decline of arrivals, under these conditions they do not reflect legitimate and legal border externalization.

Border controls per se are legitimate, and states will continue to decide sovereignly whom they allow to enter within the scope of their international obligations. Various border externalization policies will continue, as this represents the smallest common denominator of EU member states. This remains the case even if 
it is unclear whether or not a rescue by the Libyan Coast Guard really is a rescue. However, if the illegal practices stop and the situation in the concerned third states change and a safe place and fair procedures could be guaranteed, border externalization could become not only effective but also legal and more legitimate in the future. Nevertheless, agreement on effective migration governance including disembarkation and relocation and standards of asylum procedures, not only returns, is necessary even then. Section 4.2 outlined possible ways forward.

In governing the migration issue, the EU and its member states face several dilemmas. So far, the dilemmas prevent real progress toward effective asylum and migration policies, and the resulting deadlock prevents solidarity from being provided to overburdened EU frontline states as well as to the migrants.

The five-year old EU-Turkey agreement, together with border closures within Europe, contributed to the reduction of irregular border crossings also by boat. The agreement furthermore aims at improving the situation of Syrian refugees in Turkey. Deaths in the Aegean Sea also declined. However, the planned unburdening of the Greek camps and, in turn, the opening of legal routes from Turkey to the EU have largely failed (Adar, Angenendt, Asseburg, Bossong and Kipp 03.2020; Tagesschau 18.03.2021).

Various actors made extensive efforts to promote rescue operations from 2014 to 2018. Nowadays, however, sea rescue operations are hardly ever performed by EU actors, and border management is outsourced.

Meanwhile, the number of arrivals reduced considerably but still fluctuates. It can be estimated that one to two percent of migrants on these routes remain dead or missing. At the same time, the number of unreported cases remains difficult to estimate.

The migrants in the Mediterranean Sea are not classical maritime emergency cases; they react to open and closed borders and sea rescue operations as opportunities. But if the reasons for flight are too severe - for example the attacks on civilians in the Syrian War or the wider context of political economy - then other factors contribute to the choice to take dangerous boat trips. This result fits the study by Cusumano and Villa on the Central Mediterranean route: "SAR operations conducted by European authorities and NGOs have played an important role in reducing the deadliness of sea crossings without significantly contributing to incentivizing irregular migration" (Cusumano and Villa 2020:202). UNHCR expects that violence in the Sahel region of Africa and the worsening situation in countries of refuge due to the Corona pandemic will lead to more people taking dangerous escape routes across the Mediterranean (Tagesschau 05.02.2021).

The failure to reform EU migration policy due to internal rifts and conflicting interests within the EU can have a serious effect on Europeans peace and security and that of its neighborhood. This plays into the hands of right-wing or populist parties, who call for strong national policies in order to increase their election results.

There are three arguments that we can draw on to convince the relevant actors to overcome their divide. First, we can highlight the humanitarian consequences of their actions or inaction. There is still an urgent need for a well-managed European migration system including a reduction of the deadliness of sea crossings, prevention of push-backs and "rescues" to unsafe havens. "A sustainable and effective asylum system is [the] key in securing humanitarian values while migration is also furthering economic and societal progress", Parusel points out (Parusel 2020:vii). Or as Weihe, speaker of Sea-Watch puts it: "We must not get used to this disaster!" (United4Rescue 22.10.2020, translated).

Second, we can emphasize that this has led to a crisis with regard to the EU's internal self-image, legitimacy and external normative power. One indication of the EU's disturbed self-image are the protests from civil society against the EU's refugee policy. Heinrich Bedford-Strohm, Chairman of the Protestant Church Council in Germany (EKD) for example stated that "Europe will lose its soul if it does not act according to its own fundamental beliefs" (ARD 29.03.2021). But also exercising normative, soft power toward more human rights protection in its external relations can be hampered. Recently, China responded to the EU sanctions by saying that the EU is not qualified to play the role of a human rights teacher (Tagesschau 23.03.2021).

Third, we can note that the problem cannot be wished away and that there is a risk that migrants will take matters into their own hands, leading to further violence, while there are also opportunities and chances that arise from migration for the recipients. At the same time, better border protection should address the relevant security concerns. The EU must find a balance between its legal and moral obligations.

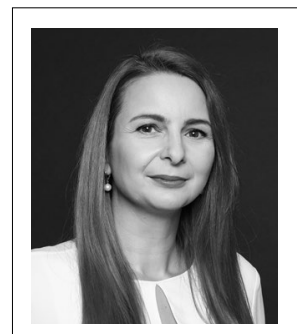

Dr. phil. Patricia Schneider is Senior Researcher at the Institute for Peace Research and Security Policy at the University of Hamburg (IFSH). She is the Academic Coordinator and a lecturer of the Master Program "Peace and Security Studies" and Managing Editor of S+F. Her main research areas are maritime security /Ocean Governance, international terrorism, international jurisdiction and (maritime) migration.

\section{References}

À PROPOS. (2020) Displacement crisis. New paradigm and struggle for behavioral change à propos. Available at https://www.swisspeace.ch/apropos/displacement-crisis-newparadigm-and-struggle-for-behavioral-change/. (Accessed February 12, 2021).

Adar, Sinem, Steffen Angenendt, Muriel Asseburg, Raphael Bossong, AND David KipP. (03.2020) Das Flüchtlingsdrama in Syrien, der Türkei und Griechenland. Warum ein umfassender Ansatz nötig ist. SWP-Aktuell (22).

AMNESTY INTERNATIONAL. (2020) Malta. Waves of Impunity: Malta's human rights violations and Europe's responsibilities in the Central Mediterranean.

Angenendt, Steffen, Nadine Biehler, Raphael Bossong, David KipP, and Anne Koch. (09.2020) Das neue EU-Migrations- und Asylpaket. SWP-Aktuell 78.

ARD. (29.03.2021) Wir schicken ein Schiff. Seenotrettung imAuftrag der Kirche. Avail able at https://www.daserste.de/information/reportage-dokumentation/dokus/sendung/ wir-schicken-ein-schiff-100.html. (Accessed March 29, 2021).

ÄrZTE OHNE GRENZFN. (03.04 2019) Offener Brief an die Bundeskanzlerin. Drei Forderungen aus der Zivilgesellschaft: Notfallplan für Bootsflüchtlinge /. Available at https://www. aerzte-ohne-grenzen.de/sites/germany/files/2019-seenotrettung-mittelmeer-offenerbrief-bundeskanzlerin.pdf. (Accessed March 5, 2021).

AuswärTIges AMT, Ed. (2020) Together for Europe's recovery. Programme for Germany's Presidency of the Council of the European Union.

BBC NEws. (28.03.2019) Migrant ship capture. Maltese armed forces take control of hijacked tanker. $B B C$ News.

BeNDiEK, ANNEgRet, AND RAPHAEL Bossong. (08.2019) Grenzverschiebungen in Europas Außen- und Sicherheitspolitik. Rechtsstaatliche Defizite überwinden. SWP-Aktuell 19.

Bossong, Raphael. (12.2019) The Expansion of Frontex. Symbolic Measures and Long-term Changes in EU Border Management. SWP-Aktuell 47. 
Buddelmann, KaI, AND Jan Phillip Graf. (08.12.2020) A pushback against international law? Legal Analysis of Allegations Against the FRONTEX Mission in the Mediterranean. Völkerrechtsblog.

CAMBRidge Dictionary. (10.02.2021) Dilemma. Available at https://dictionary.cambridge. org/de/worterbuch/englisch/dilemma. (Accessed February 10, 2021).

Carrera, Sergio. (09.2020) Whose Pact? The Cognitive Dimensions of the New EU Pact on Migration and Asylum. CEPS Policy Insights 2020-22. Brussels.

COUNCIL OF THE EUROPEAN UNION. (05.03.2021) Lives saved in EU Mediterranean operations (2015-2021). Data up to February 2021. Available at https://www.consilium.europa. eu/en/infographics/saving-lives-sea/. (Accessed March 26, 2021).

Cusumano, Eugenio. (2018) Migrant rescue as organized hypocrisy. EU maritime missions offshore Libya between humanitarianism and border control. Cooperation and Conflict 54 (1): 3-24.

Cusumano, Eugenio, AND Kristof GombeER. (2020) In deep waters. The legal, humanitarian and political implications of closing Italian ports to migrant rescuers. Mediterranean Politics 25 (2): 245-253.

Cusumano, Eugenio, and Matteo Villa. (2020) Over troubled waters:. maritime rescue operations in the Central Mediterranean Route. In Migration in West and North Africa and across the Mediterranean. Trends, risks, development and governance, edited by Philippe Fargues and Marcia Rango. Geneva: International Organization for Migration: 202-214.

Deleixhe, Martin, ANd Denis Duez. (10.2019) The new European border and coast guard agency. Pooling sovereignty or giving it up? Journal of European Integration 41 (7): 921-936.

DeutsChe WelLe. (07.06.2020) Malta lässt 425 Migranten an Land. Available at https:// www.dw.com/de/malta-1\%C3\%A4sst-425-migranten-an-land/a-53717429. (Accessed February 12, 2021).

Deutsche Welle. (03.07.2020) Selbstmordversuche und Hungerstreik auf der „Ocean Viking“. Available at https://www.dw.com/de/selbstmordversuche-und-hungerstreikauf-der-ocean-viking/a-54044500. (Accessed February 10, 2021).

DEUTSCHER BundESTAG. (03.02.2021) Antwort der Bundesregierung. auf die Kleine Anfrage der Abgeordneten Andrej Hunko, Michel Brandt, Heike Hänsel, weiterer Abgeordneter und der Fraktion DIE LINKE. Drucksache 19/26416. Available at https://dip21.bundestag. de/dip21/btd/19/264/1926416.pdf. (Accessed March 29, 2021)

EHRHART, HANs-GEORG. (2013) Konzeptionelle Grundlagen. In Piraterie und maritimer Terrorismus als Herausforderungen für die Seehandelssicherheit Deutschlands. Politik, Recht, Wirtschaft, Technologie, edited by Hans-Georg Ehrhart, Kerstin Petretto, Patricia Schneider, Thorsten Blecker, Hella Engerer and Doris König. Baden-Baden: Nomos: 27-38.

EUROPEAN COMMISSION. (23.09.2020a) Communication from the Commission on a New Pact on Migration and Asylum. Building confidence and striking a new balance between responsibility and solidarity. COM(2020) 609 final. Available at https://eur-lex.europa. eu/legal-content/EN/TXT/?qid=1601287338054\&uri=COM\%3A2020\%3A609\%3AFIN.

EUROPEAN COMMISSION. (23.09.2020b) Empfehlung der Kommission zu legalen Schutzwegen in die EU:. Förderung der Neuansiedlung, der Aufnahme aus. Available at https://ec.europa.eu/info/sites/info/files/recommendation-promoting-resettlmenthumanitarian-pathways_de.pdf. (Accessed February 12, 2021).

European Commission. (23.09.2020c) New Pact on Migration and Asylum. Questions and Answers. Available at https://ec.europa.eu/commission/presscorner/detail/en/ qanda_20_1707.

EUROPOL. (2019) Migrant smuggeling 2019. The profits of smugglers.

EUROPOL, AND INTERPOL. (2016) Migrant Smuggeling Networks. Joint Europol-INTERPOL Report. Executive Summary.

FERNANDEZ, MAÏTÉ. (2016) Multi-stakeholder operations of border control coordinated at the EU level and the allocation of international responsibilities. In Human Rights and the Dark Side of Globalisation, edited by Thomas Gammeltoft-Hansen and Jen Vedsted-Hansen. Abingdon, New York, NY: Routledge, 2016. |: Routledge: 252-285.

FItZGerald, DAVID. (2019) Refuge beyond reach. How rich democracies repel asylum seekers. Oxford: Oxford University Press.

Frelick, Bill, IAN M. Kysel, AND JenNIFER PODKUL. (08.08.2016) The Impact of Externalization of Migration Controls on the Rights of Asylum Seekers and Other Migrants. Journal on Migration and Human Security 4 (4): 190-220.

Frontex. (03.2016) Annual Risk Analysis 2016. Warsaw.

Frontex. (03.2020) Annual Risk Analysis 2020. Warsaw.

FunKE, BENEDIKT. (2018) Shaping the Discourse. How Search and Rescue NGOs Got Under Fire in the Debate on Migration. S+F Sicherheit und Frieden 36 (3): 159-164.

FunKe, BenedikT. (2021, forthcoming) Voices from Liminality. Civil-society Search and Rescue Organization as agents of migration de-securitization. In Power in Vulnerability. A Multi-Dimensional Review of Migrants' Vulnerabilities, edited by Annette Jünemann, Nicolas Fromm, Sandra Göttsche, Hamza Safouane. Wiesbaden: VS Verlag für Sozialwissenschaften.

GuILD, ELSPETH. (2016) The Dark Side of Globalisation. Do EU border controls contribute to death in the Mediterranean? In Human Rights and the Dark Side of Globalisation, edited by Thomas Gammeltoft-Hansen and Jens Vedsted-Hansen. Abingdon, New York, NY: Routledge, 2016. |: Routledge: 314-331.

HEFLIK, KATHARINA. (06.03.2021) EU-Grenzschutzbehörde. Verwaltungsrat fordert mehr Transparenz von Frontex. Die Zeit.

Hirsch, Asher Lazarus, and Nathan David Bell. (2017) The right to have rights as a right to enter. Addressing a lacuna in the International Refugee Protection Regime. Human Rights Review 18 (4): 417-437.

Howden, Daniel, Apostolis Fotiadis, And Zach Campbell. (12.03.2020) Revealed. The great European refugee scandal. The Guardian.

IMO Maritime SAFETY COMMITTEE. (adopted on 20 May 2004) Annex 34 Resolution MSC.167(78) Guidelines on the Treatment of Persons rescued at sea.
IUVENTA 10. (04.03.2021) Italian prosecutor presses charges against Search and Rescue Crew from the Mediterranean Sea.

Jünemann, ANNEtTe, Nikolas Scherer, Nicolas Fromm, Eds. (2017) Fortress Europe? Wiesbaden: Springer Fachmedien Wiesbaden.

LiguORI, ANNA. (03.2019) Migration Law and the Externalization of Border Controls. European State Responsibility. London: Routledge, Taylor \& Francis Group.

MCKINSEY, KITTY. (2014) UNHCR calls for urgent European action to end refugee and migrant deaths at sea. Available at https://www.unhcr.org/news/latest/2014/7/53d0e2d26/ unhcr-calls-urgent-european-action-end-refugee-migrant-deaths-sea.html. (Accessed February 10, 2021)

MEDIENDIENST INTEGRATION. (08.02.2021) EU-Asylpolitik. Available at https://mediendienstintegration.de/migration/flucht-asyl/eu-asylpolitik.html. (Accessed February 8, 2021).

Monroy, Matthias. (12.06.2020) Frontex-Flugzeuge. Unter dem Radar gegen das Völkerrecht. Netzpolitik.

Odwyer, CAOIMHE. (29.08.2018) A Postcolonial Analysis of the European 'Migrant Crisis'. Available at https://www.e-ir.info/2018/08/29/a-postcolonial-analysis-of-the-europeanmigrant-crisis/. (Accessed February 12, 2021).

Oflufrs-Frahm, Karin. (2019) Italien und die Rettung von Migranten. Archiv des Völkerrechts (AVR) 57 (3): 345-358.

Parusel, Bernd. (2020) Pieces of the puzzle. Managing Migration in the EU. Brussels: European Liberal Forum.

Pietz, Tobias, AND Lennart Ladewig. (22.03.2021) Ein Jahr Operation Irini. erste Lehren, neue Chancen. ZIF Analyse. zif kompakt.

ReinKe DE Buitrago, Sybille. (2017) The Meaning of Borders for National Identity and State Authority. In Border politics. Defining spaces of governance and forms of transgressions, edited by Cengiz Günay and Nina Witjes. Cham: Springer International Publishing: 143-158.

ReinKe de Butrago, Sybille, and Patricia Schneider. (2020) Ocean Governance and Hybridity. Global Governance: A Review of Multilateralism and International Organizations 26 (1): $154-175$

Riedel, Rafat. (11. 2019) Populism Is the Only Game In Town. Poland's Illiberal Turn as an Authoritarian Threat. S+F. Sicherheit und Frieden. Security and Peace 37 (1): 24-28.

Riedel, SABINE. (2020) Grenzschutz, Migration und Asyl. SWP-Studie 2020/S 23.

Ripsman, Norrin M., JefFrey W. Taliaferro, and Steven E. Lobell. (2016) Neoclassical realist theory of international politics. New York, NY: Oxford University Press.

SCHNEIDER, PATRICiA. (2016) Migranten und Flüchtlinge als Herausforderung für Deutschland und Europa. S+F. Sicherheit und Frieden. Security and Peace 34 (1): 1-19.

SCHNEIKER, ANDREA. (2017) Sicherheit in den Internationalen Beziehungen. Theoretische Perspektiven und aktuelle Entwicklungen. Wiesbaden: Springer VS.

SONG, SARAH. (2018) Immigration and Democracy: Oxford University Press.

SPIEGEL ONLINE. (23.03.2021) Mittelmeer. »Ocean Viking « darf mehr als hundert Geflüchtete nach Sizilien bringen. DER SPIEGEL

SPIEgEL ONLINE. (24.03.2021) Wegen illegaler Pushbacks. EU-Parlament verweigert Bestätigung des Budgets von Frontex. DER SPIEGEL.

TAgesschau. (20.01.2021) Schiffsunglück. 43 Menschen sterben vor Libyens Küste tagesschau.de.

TAGESSCHAU. (28.01.2021) Kritik an EU-Flüchtlingspolitik. „Pushbacks sind einfach illegal“. tagesschau.de.

TAgesschau. (05.02.2021) 800 Menschen interniert. Libyscher Küstenschutz stoppt Migranten. tagesschau.de.

TAGessCHAU. (07.02.2021) Rettungsschiff „Ocean Viking“. Migranten können in Sizilien von Bord. tagesschau.de.

TAGESSCHAU. (18.03.2021) Fünf Jahre EU-Türkei-Abkommen. Erfolgreich oder gescheitert? tagesschau.de.

TAGESSCHAU. (23.03.2021) Streit über Sanktionen. Deutschland bestellt Chinas Botschafter ein. tagesschau.de.

UN Human Rights COUNCIL. (24.04.2013) Report of the Special Rapporteur on the human rights of migrants, François Crépeau. Regional study: management of the external borders of the European Union and its impact on the human rights of migrants $\mathrm{A} / \mathrm{HRC} / 23 / 46$

UNHCR. (26.01.2007) Advisory Opinion on the Extraterritorial Application of NonRefoulement Obligations under the 1951 Convention relating to the Status of Refugees and its 1967 Protocol.

UNHCR. (30.01.2019) Desperate Journeys. Refugees and migrants arriving in Europe and at Europe's borders. January - December 2018.

UNHCR. (07.07.2020) Arrivals to Europe fromLibya - May 2020. Avail abl eat https://data2 unhcr.org/en/documents/details/77525. (Accessed March 29, 2021).

UNHCR. (10.02.2021) Mediterranean Situation. Operational Portal Refugee Situations. Available at https://data2.unhcr.org/en/situations/mediterranean. (Accessed February 10, 2021)

United4Rescue. (22.10.2020) Interview Mattea Weihe, Spokesperson for Sea-Watch. Available at https://www.united4rescue.com/logbuch/22102020-interview-mit-matteaweihe-sprecherin-von-sea-watch. (Accessed March 23, 2021).

United4Rescue. (16.02.2021) Interview zur aktuellen Lage der Schiffe Sea-Watch $3 \& 4$. Interview Mattea Weihe. Available at https://www.united4rescue.com/ logbuch/16022021-mattea-weihe-ueber-die-aktuelle-lage-der-sea-watch-3-und-seawatch-4. (Accessed March 23, 2021)

Vradis, Antonis, Evie Papada, And Joe Painter. (15.11.2019) New Borders. Hotspots and the European Migration Regime. London: Pluto Press.

Wissenschaftliche Dienste Deutscher Bundestag (2017) Sachstand. Rechtsfragen be Seenotrettungseinsätzen innerhalb einer libyschen SAR-Zone im Mittelmeer. 